\title{
ANALYSIS OF TAXATION BURDEN IN UKRAINE IN 2014-2016
}

\author{
Natalia Selivanova ${ }^{1}$ \\ Odessa National Polytechnic University, Ukraine \\ Liudmyla Tokarchuk ${ }^{2}$, Oleg Chuvakov ${ }^{3}$ \\ Odesa l.I. Mechnikov National University, Ukraine
}

\begin{abstract}
Tax relations of enterprises with a state take a significant place in their state and economic life, as it is evidenced by the appearance of tax accounting, which is fixed in legislation. The analysis of burden of taxation is rather a relevant issue for Ukraine's economy at the present stage of development because the rate of the burden of taxation is the main criterion of efficiency of the state's tax system, the formation of which is tried to be initiated in the project of Tax Code. Because of the insufficient level of the burden of taxation, the government budget receives fewer means, and that's why the government of the state won't be able to perform their functions effectively and completely. To provide the optimum level of the burden of taxation is one of the first-priority tasks of the tax system of each country. The purpose of the paper is to research the existing practice of taxation of activity of the enterprises of Ukraine, which allows analysing the tendencies of the level of burden of taxation according to the norms of tax law and developing proposals for its optimization. Methodology. The informational and methodological base of research is the statistical data of the Ministry of Finance of Ukraine, the official site of the State Statistics Service of Ukraine, laws and regulations concerning taxation in Ukraine, materials of scientific periodicals and the Internet resources. To achieve the purpose of the research, the following methods have been used: knowledge of formal and dialectic logic, systemic and structural analysis. Results. The tendencies of the burden of taxation in Ukraine have been analysed according to such directions: analysis of types of charged payments to the state budget of Ukraine, analysis of volumes of compensation on value-added tax, analysis of new taxes and fees for an individual, analysis of burden of taxation in Ukraine according to the international ratings. The conducted researches showed that strengthening of rating of our country in the world economic scope in general and in different spheres in particular (trade, financial, social and so on) is impossible without the formation of the strong internal basis for development, which tax system provides. Ukraine has the potential for improvement of institutional, administrative, and economic levers in this sphere. Along with this, it is necessary to avoid actions, which allow "artificially" increase the rating of the country without real improvement in this sphere, because it can influence image and reputation of the country negatively, arousing mistrust towards the system of state administration and regulation. Practical implications. The recommendations, offered by the authors, according to the results of the research, can be useful both for the developers of the economic policy and for the subjects of business activity for the purpose of optimization of the burden of taxation in the country. Value/originality. The originality of the research, which has been carried out by the authors, is in the justification of the factors that influence the level of burden of taxation of business in Ukraine and the development of proposals concerning its optimization for the purpose of simplification of the burden of taxation on businessmen of the country.
\end{abstract}

Key words: burden of taxation, tax system, taxes, fees, state budget, value added tax, personal income tax, taxation indicator.

JEL Classification: H24, H61, K34

\footnotetext{
Corresponding author:

${ }^{1}$ Department of Accounting, Analysis and Audit, Odessa National Polytechnic University.

E-mail: n.selivanova.odessa@gmail.com

${ }^{2}$ Department of Civil Law Disciplines, Odesa I.I. Mechnikov National University.

E-mail: zilkovska@ukr.net

${ }^{3}$ Department of Criminal Law, Criminal Procedure and Criminalistics, Odesa I.I. Mechnikov National University.

E-mail:anyuta@te.net.ua
} 


\section{Introduction}

Development of enterprises and creation of the favourable environment for it is the first-priority task of the state, because "a free hand of a market" does not always allow providing necessary and equal conditions. Importance of assessment of such conditions and their comparability in different countries of the world for investors, creditors, and other interested people ("stakeholders") are caused by their interest to the condition of development, specific conditions and protection of their interests. From this standpoint, the assessment of the factor of the taxation burden is the basic reference point with the organizational and methodical provision of the accounting policy of an enterprise.

Theoretical basis and practical questions of development of taxation system are lit in the works of domestic and foreign authors. The question of burden of taxation, its influence on economic activity and financial results of payers, reasons and its consequences of uneven distribution among the subjects of business entities, tendencies and the ways of change are laid down in the works of domestic economists O. Balan, V. Savchenko, L. Shablista, A. Sokolovska, Z. Varnaliy, V. Vishnevskiy. The authors of the last publications, who considered questions of taxes and burden of taxation in Ukraine and in the world, are I. Bilous, G. Datsenko, N. Korkun, O. Korotkevich, N. Lokhanova, I. Lomachynska, Y. Panura, M. Stepura, O. Timchenko.

During 2014-2016, the government of Ukraine carried out the tax and budget policy on the background of the unstable development of the world economy and instability in the international financial market. The filling of the budget's revenues occurred in the conditions of the reformed tax law, according to the norms of the Tax Code of Ukraine. The analysis of burden of taxation is rather a relevant issue for Ukraine's economy at the present stage of development because the rate of the burden of taxation is the main criterion of efficiency of the state's tax system.

The purpose of the paper is to research the existing practice of taxation of activity of the enterprises of
Ukraine, which allows analysing the tendencies of the level of burden of taxation according to the norms of tax law and developing proposals for its optimization.

The following main directions of the analysis of the burden of taxation in Ukraine are offered and presented by such spheres (Figure 1).

The informational and methodological base of research is the statistical data of the Ministry of Finance of Ukraine, State Fiscal Service of Ukraine, Public Service of Statistics of Ukraine, laws and regulations concerning taxation in Ukraine, materials of scientific periodicals and the Internet resources. To achieve the purpose of the research, the following methods have been used: analysis and synthesis methods, knowledge of formal and dialectic logic, comparative, systemic, and structural analysis.

\section{The structure of charged payments to the state budget of Ukraine}

The first direction of analysis of the burden of taxation in Ukraine is the analysis of types of charged payments to the state budget of Ukraine.

The following features can be highlighted among the features of the filling of the budget's revenues in 2014-2016 (Table 1).

So, in the dynamics for 2014-2016, the largest specific weight, in the structure of tax payments and fees, occupies the value-added tax on the goods imported to the territory of Ukraine (38.3\% in 2014, 33.9\% in 2015 and $36.0 \%$ in 2016).

Along with it, it is possible to note the growth in the structure of tax payments of the amount of the personal income tax for three years (from $4.5 \%$ in 2014 to $11.9 \%$ in 2016), that is due to the increase of a tax rate and the increase of a salary.

The situation concerning the amount of taxes except the grants on manufacturing and import in a section of branches of the economy for 2014-2016 is the following (Table 2).

As we can see from Table 2, the main and the largest budget's fillings are: 1) agriculture, forestry and fishery; 2) building; 3) wholesale and retail trade; 4) repair

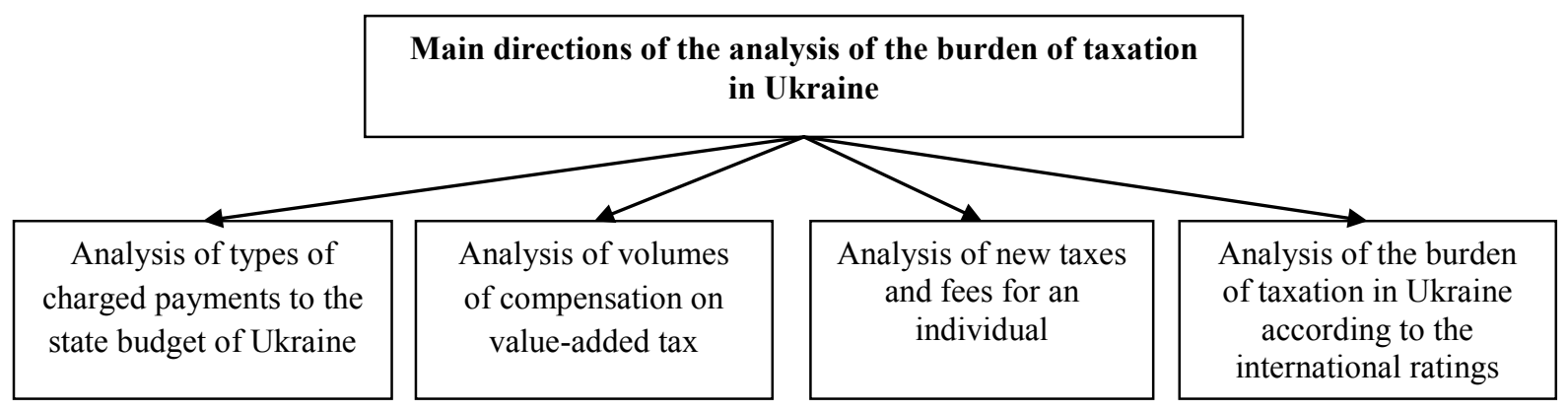

Figure 1. Directions of the analysis of taxation burden in Ukraine

Source: developed by the authors 
Table 1

Charges to the state budget of Ukraine in a section of separate payments, as a component of the analysis of Ukraine's burden of taxation

\begin{tabular}{|l|c|c|c|c|c|c|}
\hline \multicolumn{1}{|c|}{\begin{tabular}{l} 
Types of tax payments to the state's budget \\
\multicolumn{1}{|c|}{ of Ukraine }
\end{tabular}} & \multicolumn{2}{c|}{ As of 31.12.2014 } & \multicolumn{2}{c|}{ As of 31.12.2015 } & \multicolumn{2}{c|}{ As of 31.12.2016 } \\
\cline { 2 - 7 } & mln UAH & $\%$ & mln UAH & $\%$ & mln UAH & $\%$ \\
\hline Enterprise tax & 39941.9 & 14.3 & 34776.3 & 8.5 & 54344.1 & 10.8 \\
\hline Personal income tax & 12645.8 & 4.5 & 45062.0 & 11.0 & 59810.5 & 11.9 \\
\hline $\begin{array}{l}\text { Collecting and payment for special use of natural } \\
\text { resources }\end{array}$ & 19036.1 & 6.8 & 39803.8 & 9.7 & 44092.2 & 8.8 \\
\hline $\begin{array}{l}\text { Excise tax on the excise goods manufactured in } \\
\text { Ukraine }\end{array}$ & 28085.5 & 10.0 & 38783.8 & 9.5 & 55116.3 & 10.9 \\
\hline $\begin{array}{l}\text { Excise tax on imported excise goods on the } \\
\text { customs territory of Ukraine }\end{array}$ & 16855.4 & 6.0 & 24326.8 & 5.9 & 35006.2 & 6.9 \\
\hline $\begin{array}{l}\text { Value-added tax on goods manufactured in Ukraine } \\
\text { (taking into account budgetary compensation) }\end{array}$ & 31737.0 & 11.3 & 39688.0 & 9.7 & 54052.7 & 10.7 \\
\hline $\begin{array}{l}\text { Value-added tax on goods imported to the territory } \\
\text { of Ukraine }\end{array}$ & 107287.3 & 38.3 & 138764.3 & 33.9 & 181453.3 & 36.0 \\
\hline $\begin{array}{l}\text { Taxes on international trade and external operation } \\
\text { Rent payment and fees on fuel and energy }\end{array}$ & 12608.7 & 4.5 & 40300.8 & 9.8 & 20371.0 & 4.0 \\
\hline resources & 5987.5 & 2.1 & 7245.4 & 1.8 & 279.0 & 0.1 \\
\hline Other taxes and fees & 5993.1 & 2.1 & 666.2 & 0.2 & -645.8 & -0.1 \\
\hline Total & 280178.3 & 100 & 409417.5 & 100 & 503879.4 & 100 \\
\hline
\end{tabular}

Source: systematized by the authors (State Fiscal Service of Ukraine, 2014-2016)

Table 2

Taxes except for the grants on manufacturing and import $i$ $n$ a section of branches of the economy for 2014-2016 (mln UAH)

\begin{tabular}{|l|c|c|c|}
\hline \multicolumn{1}{|c|}{ Branch of economy } & \multicolumn{2}{c|}{ Years } \\
\cline { 2 - 4 } & 2014 & 2015 & 2016 \\
\hline Agriculture, forestry, and fishery & 1353 & 1389 & 223 \\
\hline Extractive industry and development of quarries & -7595 & -385 & 10167 \\
\hline Processing industry & 6044 & 6563 & 1274 \\
\hline Electrical supply, gas supply, supply with steam and air conditioning & -7517 & -3649 & -258 \\
\hline Water supply; sewerage, wastes handling & -1245 & -869 & 2463 \\
\hline Building & 1198 & 1612 & 5983 \\
\hline Wholesale and retail trade; repair of vehicles and motorcycles & 4431 & 3969 & 1554 \\
\hline Transport, stores, post and express activity & 1068 & 1289 & 308 \\
\hline Temporary placement and catering services & 427 & 310 & 3422 \\
\hline Information and telecommunications & 1697 & 2856 & 2802 \\
\hline Financial and insurance activity & 1397 & 1769 & 1152 \\
\hline Real estate transaction & -2238 & 742 & 2318 \\
\hline Professional, scientific and technical activity & 1336 & 1605 & 1131 \\
\hline Activity in the sphere of administrative and support service & 770 & 789 & 180 \\
\hline State administration and defence; obligatory social insurance & 91 & 118 & 191 \\
\hline Education & 107 & 130 & 478 \\
\hline Health protection and providing social assistance & 188 & 339 & -2683 \\
\hline Art, sport, entertainments and recreation & -1993 & -2328 & 766 \\
\hline Providing other types of service & 476 & 505 & 34724 \\
\hline Total & -5 & 16754 & \\
\hline
\end{tabular}

Source: systematized by the authors (State Fiscal Service of Ukraine, 2014-2016; Public Service of Statistics of Ukraine, 2014-2016)

of vehicles and motorcycles; 5) processing industry; 6) information and telecommunications; 7) financial and insurance activity. The following branches continue to be granted: a) water supply; sewerage, wastes handling; b) art, sport, entertainments and recreation. It also should be noted that there is a positive tendency of taxes increase in absolute measures in 2015 and 2016, and it displays the improvement according to the results of 2014 in 5 million UAH.

The second offered direction of analysis of Ukraine's burden of taxation is the analysis of volumes of compensation on value-added tax. 
Table 3

Volumes of compensation on value-added tax from the state's budget by years (mln UAH), as a component of the analysis of Ukraine's burden of taxation

\begin{tabular}{|l|c|c|c|c|c|c|}
\hline Period & $\begin{array}{c}\text { The rest of the } \\
\text { sums stated before } \\
\text { the compensation } \\
\text { for the beginning } \\
\text { of the period } \\
\text { (year) }\end{array}$ & $\begin{array}{c}\text { Compensations } \\
\text { paid in cash }\end{array}$ & $\begin{array}{c}\text { Enlisted sums, } \\
\text { stated into } \\
\text { accounts of payers, } \\
\text { in the reduction of } \\
\text { tax obligations }\end{array}$ & $\begin{array}{c}\text { Rejected sums, } \\
\text { stated before the } \\
\text { compensation } \\
\text { on the current } \\
\text { account }\end{array}$ & $\begin{array}{c}\text { New sums, } \\
\text { stated before the } \\
\text { compensation into } \\
\text { the account of a } \\
\text { payer }\end{array}$ & $\begin{array}{c}\text { The rest of the } \\
\text { sums stated before } \\
\text { the compensation } \\
\text { for the end of the } \\
\text { period }\end{array}$ \\
\hline For 01.01.2017 & 12876.4 & 94405.4 & 1963.0 & 1217.4 & 94857.6 & 12172.2 \\
\hline For 01.01.2016 & 13499.7 & 68405.3 & 38096.1 & 2454.1 & 855.4 & 71654.3 \\
\hline For 01.01.2015 & - & 1237.7 & - & - & - & - \\
\hline
\end{tabular}

Source: systematized by the authors (Ministry of Finance of Ukraine 2014-2017)

In practice, taxation of different states of the world can be allocated into a number of taxes that got universal recognition, one of which is the value-added $\operatorname{tax}$ (VAT). On the background of the performance of tax obligations by Ukraine's enterprises, receiving compensation of value added tax becomes the actual issue and it is a significant part of financial resources for the enterprises, and the existing situation of this issue is highlighted in Table 3.

The discrepancy between the tax revenue of VAT to the budget and the financial needs of the state aggravates the problem of increase in efficiency of administration of this tax and the search of funds concerning the increase of revenues of this tax, because the deficiency of financial resources affects negatively on welfare of the population, and it does not only deepen the crisis phenomena in the economy but also complicates the process of their overcoming.

\section{New taxes and fees for an individual in Ukraine for 2014-2016}

The next offered direction of the analysis of Ukraine's burden of taxation is the analysis of new taxes and fees for an individual. In order to carry out the revenues to the budget, new taxes and fees, which concern individuals, were introduced in 2014, but in 2015-2016 the taxes rates were continued and changed (Table 4).

According to Table 4, it can be seen that the main changes, which have been provided by Ukraine's Law from the $24^{\text {th }}$ of December 2015 №909-VIII "On Modification to the Tax Code of Ukraine and Some Acts of Ukraine, Concerning the Provision of Balance of the Budgetary Revenues in 2016" (Verkhovna Rada of Ukraine, 2016), are the following:

1) The income tax on an individual - the rates have been changed. Earlier it was $15 \%$ for monthly income up to 10 sizes of the minimum wage (for the $1^{\text {st }}$ of January 2016 - $13780 \mathrm{UAH}$ ) and $20 \%$ from the excess sum, but now $18 \%$ is used to any sum of income.

The exception is made by pensioners, who receive over three sizes of the minimum wage (from the $1^{\text {st }}$ of January 2016 - $4134 \mathrm{UAH}$ ), and from the sum of such excess, the income tax copes with a rate of $15 \%$.

2) For the incomes, charged as a win or a prize in favour of residents or non-residents, the rate of the income tax is $0 \%$ (but earlier it was a double size of taxation basis, or $30 \%$ ).

3) Passive incomes: the rate of income tax is $18 \%$ (earlier it was 20\%), except the dividends on shares and

Table 4

New taxes and fees for an individual, as a component of the analysis of Ukraine's burden of taxation for 2014-2016

\begin{tabular}{|c|c|c|c|}
\hline Taxes & 2014 & 2015 & 2016 \\
\hline The tax on passive income, including on deposits & $15 \%$ & $20 \%$ & $18 \%$ \\
\hline The tax on pensions & $15 \%$ (from 10 thsd. UAH) & $\begin{array}{c}15 \%(3654 \mathrm{UAH}) \\
\text { if the sum is more than } \\
12180 \mathrm{UAH}-20 \%\end{array}$ & $\begin{array}{c}15 \%(3654 \mathrm{UAH}), \\
\text { if the sum is more than } \\
12180 \mathrm{UAH}-20 \%\end{array}$ \\
\hline $\begin{array}{l}\text { The tax on the housing real estate: } \\
\text { 1) preferential meters have not been changed - } 60 \\
\mathrm{~m}^{2} \text { for flats and } 120 \mathrm{~m}^{2}-\text { for houses } \\
\text { 2) over } 300 \mathrm{~m}^{2} \text { and for the houses over } 500 \mathrm{~m}^{2}- \\
25 \text { thsd. UAH of the tax for a year }\end{array}$ & $\begin{array}{l}1 \% \text { of the size } \\
\text { of minimum wage }\end{array}$ & $\begin{array}{l}24.36 \mathrm{UAH} \text { for } 1 \mathrm{~m}^{2} \\
\text { for a year }\end{array}$ & $\begin{array}{l}3 \% \text { of the size } \\
\text { of minimum wage }\end{array}$ \\
\hline $\begin{array}{l}\text { The fees from cars' owners with an engine } \\
\text { displacement of more than } 3 \text { thsd cc. }\end{array}$ & 25 thsd. UAH & 25 thsd. UAH & 25 thsd. UAH \\
\hline Military fees (from incomes) & $1.5 \%$ from incomes; & $1.5 \%$ from incomes; & $1.5 \%$ from incomes; \\
\hline Fees upon purchase of currency cash (from a sum) & $0.5 \%$ & $2 \%$ & $2 \%$ \\
\hline The tax on the inheritance of more than $1 \mathrm{mln}$ UAH & $5 \%$ from a sum & $5 \%$ from a sum & $5 \%$ from a sum \\
\hline
\end{tabular}

Source: systematized by the authors (Tax Code of Ukraine, 2014-2016) 
corporate rights, charged by residents-payers of profits tax of enterprises. For such revenues, the rate is $5 \%$.

Consequently, the deposits of Ukrainians raise the banking system and economy of neighbouring Poland. According to the information of the National Bank of Poland, as of the end of 2015, the citizens of Ukraine placed their deposits in Polish banks on approximately $900 \mathrm{mln}$ PLZ that makes more than $230 \mathrm{mln}$ USD. It is almost twice more than in 2014 when the size of the deposits of Ukrainians was $500 \mathrm{mln}$ PLZ (128 mln USD) (Bizresurs, 2016).

It should be noted that, in accordance with the Tax Code of Ukraine (paragraph 265.2.2 clause 265.2 item 265 ) income tax on residential property is not subject to taxation: buildings of orphanages of a family type; residential property owned by large families and foster families, which have three or more children, but no more than one such facility for the family and dormitories. These norms have a social orientation, which is a form of state support for the functioning of family-type orphanages by exempting from taxation.

\section{The comparison of Ukraine's indices of "Taxation" with indices of other countries and group of the countries}

The fourth direction of the offered analysis of the burden of taxation in Ukraine is the international rating, where the particular place is allocated by the estimation of the tax system in the country.

According to the report for 2017 (World Bank, 2017), Ukraine takes the 84th place among 190 countries by rating "Doing Business" in 2017 (Figure 2) by taxation indicator, and it is for 1 position worse in comparison with the rating "Doing Business" in 2016. At the present moment, the leader is New Zealand. By the average calculations of the experts, one point in the rating of "Doing Business" brings the state approximately 500-600 mln USD of investments.

The "Taxation" indicator is estimated by such indices as:

- a number of tax payments;

- time for calculation and payment of taxes

- general tax rate (\% from profit to taxation);

- index of procedures after submission of the reporting and payment of taxes, which is measured on the basis of assessment: a) time, spent on calculation of compensation according to VAP; b) time, which is necessary for obtaining this compensation; c) time, which is necessary for error correction, adjustment of reporting, conducting and finishing procedures of tax audit.

We offer the evident comparison of Ukraine's indices of "Taxation" indicator with indices of other countries and group of the countries (Table 5), which was received by synthesis of reports of the Doing Business in 2017 (World Bank, 2017) and the Paying Taxes in 2017 (PwC, 2017).

The comparison shows that Ukraine has favourable conditions on such indicators as "a number of tax payments" and "the index of procedures after submission of the reporting", but too much time for calculation and payment of taxes and there is rather high general tax rate.

As it is pointed out in the report "Paying Taxes 2017" (PwC, 2017), the world companies spend on average 251 hours on the calculation of taxes, preparation of the reporting and their payment, carry out 25 payments at the average general tax rate $40.6 \%$ from profit to taxation.

In the report "Paying Taxes 2017" (PwC, 2017), Ukraine is analysed in comparison with 19 countries of Eastern Europe and Central Asia. Among these countries, Ukraine has the lowest number of tax payments (together with Georgia) - 5. In other countries, it is provided from 6 (Azerbaijan) to 51 (Kyrgyzstan) payments.

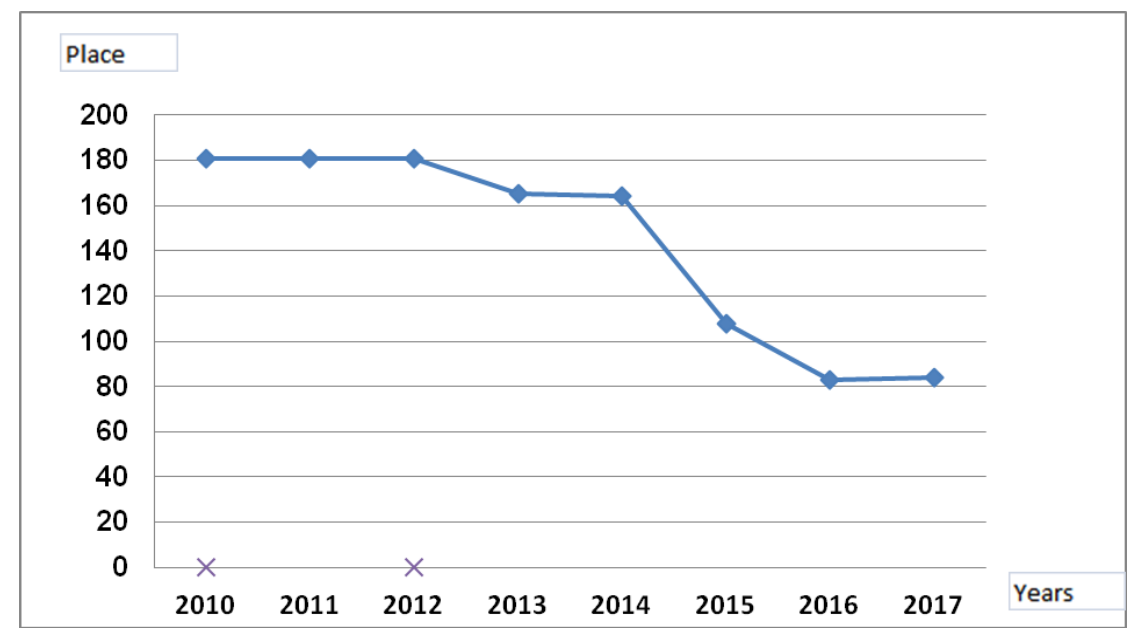

Figure 2. The position of Ukraine in the Doing Business ranking by taxation indicator by years, as a component of the analysis of Ukraine's burden of taxation Source: systematized by the authors (Doing Business, 2017; World Bank, 2017) 
Vol. 4, No. 3, 2018

Table 5

The comparison of Ukraine's indices of "Taxation" indicator with the indices of other countries and group of the countries, as a component of the analysis of the burden of taxation of Ukraine

\begin{tabular}{|l|c|c|c|c|}
\hline \multirow{2}{*}{$\begin{array}{c}\text { Countries and group } \\
\text { of the countries }\end{array}$} & $\begin{array}{c}|l| \\
\text { Andices number } \\
\text { of tax payments }\end{array}$ & $\begin{array}{c}\text { Time for calculation } \\
\text { and payment of taxes }\end{array}$ & $\begin{array}{c}\text { General tax rate } \\
\text { (\% from profit } \\
\text { to taxation) }\end{array}$ & $\begin{array}{c}\text { Index of procedures } \\
\text { after submission of the } \\
\text { reporting and payment } \\
\text { of taxes, }(0-100)\end{array}$ \\
\hline Ukraine (rating - 20) & 5,0 & 355,5 & 51,9 & 79,3 \\
\hline Europe and Central Asia & 17,6 & 221,5 & 33,8 & 71,9 \\
\hline OECD & 10,9 & 163,4 & 40,9 & 85,1 \\
\hline New Zealand (rating-2) & 7,0 & 152,0 & 34,3 & 96,9 \\
\hline Poland (rating-47) & 7,0 & 271,0 & 40,4 & 92,2 \\
\hline Georgia (rating-22) & 5,0 & 270,0 & 16,4 & 87,2 \\
\hline
\end{tabular}

Source: systematized by the authors (World Bank, 2017; PwC, 2017)

The general tax rate is one of the highest - 51.9\% (Ukraine is outstripped only by Belarus - 54.8\% and Tajikistan $65.2 \%)$. One of the highest indices is the index of time for calculation and payment of taxes - 355.5 (higher index is only in Bosnia and Herzegovina -411 hours).

According to the index of procedures after submission of the reporting, Ukraine is in the middle of this mini-rating.

It is necessary to approach such positive indicators critically. So, the reduction of a number of tax payments is substantially "artificial" taking into account the changes, which have been brought into the structure of property and resource taxes (Table 6).

As it can be seen, the taxes were not reduced; they were combined into two taxes, in which several subspecies are distinguished.

In recent years, reduction in a number of subjects of business activity is observed but the position of Ukraine is growing in the international ratings (in particular in the Doing Business and the Paying Taxes).

The strengthening of the rating of our country in the world economic scope in general and different spheres in particular (trade, financial, social, and so on) is impossible without formation of the strong internal basis for development, which is provided by the system of taxation.

Despite some positive shifts, Ukraine has the potential for the improvement of institutional, administrative, and economic levers in this sphere. Along with this, it is necessary to avoid actions, which allow "artificially" increasing the rating of the country without real improvement in this sphere because it can influence image and reputation of the country negatively, arousing mistrust towards the system of the state administration and regulation.

\section{Conclusions}

To sum up, it should be noted that improvement and optimization of the burden of taxation are connected with the solution of the following issues:

1) Improvement of administration of taxes, implementation of new approaches to the analysis of the financial-economic activity of payers, monitoring of their activity and determination the enterprises that belong to a risk group.

2) Increase of the control on completeness of declaring and timeliness of taxes payment, strengthening of work

Table 6

Transformation of a number of taxes and fees, as a component of the analysis of taxation burden of Ukraine

\begin{tabular}{|c|c|}
\hline $2011-2014$ yrs. & $2015-2017$ yrs. \\
\hline $\begin{array}{l}\text { Fee for the first registration of the vehicle } \\
\text { Payment for land } \\
\text { Real estate tax, differing from the land plot }\end{array}$ & $\begin{array}{l}\text { Property tax, which consists of: } \\
\text { - real estate tax, differing from a land plot; } \\
\text { - transport tax } \\
\text { - tax on land }\end{array}$ \\
\hline $\begin{array}{l}\text { Rent payment for transportation of oil and oil products by the main } \\
\text { oil pipelines, transit transportation of natural gas and ammonia by } \\
\text { pipelines across the territory of Ukraine }\end{array}$ & \multirow{6}{*}{$\begin{array}{l}\text { Rent payment, which consists of: } \\
\text { - rent payment for subsoil use for mining; } \\
\text { - rent payment for subsoil use for purposes not related to mining; } \\
\text { - rent payment for use of the radio-frequency resource of Ukraine; } \\
\text { - rent payment for a special use of water; } \\
\text { - rent payment for a special use of forest resources; } \\
\text { - rent payment for transportation of oil and oil products by the oil } \\
\text { pipelines, transit transportation; }\end{array}$} \\
\hline $\begin{array}{l}\text { Rent payment for oil, natural gas and gas condensate produced on } \\
\text { the territory of Ukraine }\end{array}$ & \\
\hline Payment for subsoil use & \\
\hline Fee for the use of the radio-frequency resource of Ukraine & \\
\hline Fee for a special use of water & \\
\hline Fee for a special use of forest resources & \\
\hline
\end{tabular}

Source: systematized by the authors (Tax Code of Ukraine, 2010-2017) 
with enterprises that belong to a risk group, transit and fictitious enterprises, elimination of "tax holes".

3) Avoidance of corruption risk through anticipation of a clear definition of bases for conducting unscheduled exit inspection of a payer by tax authorities for the definition of the reliability of the budgetary compensation.

4) Impossibility of registration of fictitious enterprises.

5) Introduction of special control over the activity of newly formed enterprises at the initial level (up to one year), in particular, the introduction of monthly submission of tax declarations, use of financial guarantees and separate tax audits.

6) Increase in the level of tax culture, development of the partnership, direction of tax administration activity for needs of a taxpayer.

Thus, the level of assessment of burden of taxation in Ukraine shows that taxation has a moderate character in comparison with the market-developed countries of the world and there is the basis for the formation of organizational and methodical providing of enterprise's tax policy in a part of taxation.

\section{References:}

Balan O., Maslennikov Y., Selivanova N. (2017). Identifying areas and components of the management decisions for small industrial enterprises the second and third group of simplified tax system. Marketing $i$ menedgment innovatzij - Marketing and Management of Innovations, no 3, 257-266.

Bizresurs. (2016, April 26). Ukrainzi derzhat v polskih bankah pochti $\$ 230 \mathrm{mln}$. [The Ukrainians keep in Polish banks nearly $\$ 230 \mathrm{mln}$.]. Retrieved from: http://bizresurs.com.ua/news/ukraincy-derzhat-v-polskikhbankakhpoch.html

Doing Business (2017). Retrieved from: http://doingbusiness.org

Lomachynska I. (2014). Vplyv fiskalnoi polityky derzhavy na finansovu stiikist ukrainskykh pidpryiemstv [Influence of fiscal policy on financial stability of ukrainian companies]. Visnyk Odeskoho natsionalnoho universytetu. Ekonomika. -Odesa National University herald, vol. 19, issue 2, no. 5, 173-177. (in Ukrainian)

Ministry of Finance of Ukraine (2018). Vypolneniye gosudarstvennogo byudzheta Ukrainy [Implementation of the state budget of Ukraine]. Retrieved from: https://index.minfin.com.ua/finance/budget/gov/

Public service of statistics of Ukraine (2017). Retrieved from: http://www.ukrstat.gov.ua/

PwC (2018). Paying Taxes 2017. Retrieved from: http://pwc.com/gx/en/paying-taxes/pdf/pwcpayingtaxes-2017.pdf

Savchenko V.F. \& Los A.F. (2011). Ozhinka rivnja podatkovogo navantazhnnja v Ukaine [Assessment of level of burden of taxation in Ukraine]. Economichnij chasopis - XXI - Economic Annals-XXI, no. 9/10, 25-28. (in Ukrainian)

Sokolovska A.M. (2008). Metodologichni ta metodichni aspecti viznachennja podatkovogo navantazhennja na pratzy, capital i spozhivannja [Methodological and methodical aspects of definition of burden of taxation on work, capital and consumption]. Finansy Ukrainy - Finansi Ukraini, no. 1, 65-76. (in Ukrainian)

State Fiscal Service of Ukraine (2015-2018). Plany ta zvity roboty Derzhavnoi fiskalnoi sluzhby Ukrainy Plans and reports of the State Fiscal Service of Ukraine. Retrieved from: http://sfs.gov.ua/diyalnist-/plani-ta-zvitiroboti-/237691.html

Verkhovna Rada of Ukraine (2010). Law of Ukraine. Podatkovij kodeks Ukraiyny [Tax Code of Ukraine]. No. 2755-VII. Retrieved May, 2018, from: http://zakon2.rada.gov.ua/laws/show/2755-17 (in Ukrainian)

Verkhovna Rada of Ukraine (2016). Law of Ukraine. Pro vnesennja zmin do Podatkovogo kodeksu Ukraiyny ta dejakih zakonodavchih aktiv Ukraiyny chodo zabezpechennja zbalansovanosti budzhetnih nadhodzhen u 2016. [About the introduction of amendments to the Tax Code of Ukraine and other legal acts of Ukraine concerning balance of budgetary revenues in 2016]. Retrieved May, 2018, from: zakon3.rada.gov.ua/laws/show/909-19 (in Ukrainian)

World Bank (2017). Doing business 2017: equal opportunity for all: comparing business regulation for domestic firms in 190 economies. Retrieved from: http://www.doingbusiness.org/ /media/WBG/DoingBusiness/ Documents/Annual-Reports/English/DB17-Report.pdf 